\title{
Revision of the enigmatic Southeast Asian spider genus Savarna (Araneae, Pholcidae)
}

\author{
Bernhard A. HUBER ${ }^{1, *}$, Booppa PETCHARAD ${ }^{2}$ \& Sara BUMRUNGSRI ${ }^{3}$ \\ ${ }^{1}$ Alexander Koenig Research Museum of Zoology, Adenauerallee 160, 53113 Bonn, Germany. \\ ${ }^{2,3}$ Department of Biology, Faculty of Science, Prince of Songkla University, \\ Hat Yai, Songkhla 90112, Thailand. \\ ${ }^{*}$ Corresponding author: b.huber@zfmk.de \\ ${ }^{2}$ E-mail: zigzagargiope@yahoo.com \\ ${ }^{3}$ E-mail: sarabumrungsri@gmail.com \\ ${ }^{1}$ urn:Isid:zoobank.org:author:33607F65-19BF-4DC9-94FD-4BB88CED455F \\ ${ }^{2}$ urn:lsid:zoobank.org:author:E1480A4E-3FA8-441C-A803-515B8AE7860D \\ ${ }^{3}$ urn:Isid:zoobank.org:author:41A1C40F-92E9-435E-AE77-16325C6DFBCF
}

\begin{abstract}
The genus Savarna Huber, 2005 was previously one of the most poorly known Pholcinae genera. Less than 20 specimens (representing four nominal species) were available worldwide; nothing was known about ultrastructure, natural history, or relationships. We present the first SEM data, supporting the position of the genus in Pholcinae outside the Pholcus group of genera and weakly suggesting a closer relationship with the genera Khorata Huber, 2005, Spermophorides Wunderlich, 1992, and two undescribed species of unknown affinity from Borneo. We provide the first data about microhabitat, web structure, and reaction to disturbance. We clarify the type locality of Savarna tessellata (Simon, 1901) ("Jalor, Biserat") and describe topotypical material. We describe the previously unknown male of Spermophora miser Bristowe, 1952 and transfer the species (that was previously considered incertae sedis) to Savarna as Savarna miser (Bristowe, 1952) comb. nov. Savarna baso (Roewer, 1963) is newly synonymized with $S$. miser. We describe the most northern species in the genus, Savarna kaeo sp. nov., and provide amendments to the descriptions of all previously described species.
\end{abstract}

Keywords. Pholcidae, Savarna, Southeast Asia, taxonomy, identification key.

Huber B.A., Petcharad B. \& Bumrungsri S. 2015. Revision of the enigmatic Southeast Asian spider genus Savarna (Araneae, Pholcidae). European Journal of Taxonomy 160: 1-23. http://dx.doi.org/10.5852/ejt.2015.160

\section{Introduction}

The genus Savarna Huber, 2005 was one of several genera created to accommodate species previously misplaced in Spermophora Hentz, 1841 (Huber 2005). Originally, the genus included three species, Savarna tessellata (Simon, 1901) and S. thaleban Huber, 2005 from southern Thailand, and S. baso (Roewer, 1963) from Sumatra. At that time, only four male and nine female specimens were known. The females of $S$. tessellata and $S$. baso could not be fully redescribed, either because the epigynum of the only female specimen was distorted ( $S$. tessellata) or because the abdomen of the only female 
specimen was missing ( . baso). Nothing was known about the biology of any species. No data were available about ultrastructure. No material was available for molecular work. Nothing was known about relationships within the genus or with other genera in the subfamily Pholcinae.

Recently, a fourth species was described from southern Thailand (S. kraburiensis Wongprom \& Wiwatwitaya, 2015), but none of the gaps mentioned above were addressed by the authors. The present study is based on more than 130 adult specimens newly collected in Thailand and Malaysia. We present the first SEM photos of Savarna, provide basic natural history data for all known species, and redescribe the females of $S$. tessellata and S. baso. The latter is newly synonymized with Savarna miser (Bristowe, 1952) comb. nov., whose male was previously unknown and which is redescribed and transferred from Spermophora. Molecular data have been generated for four species but will be presented in the context of a full molecular phylogeny of Pholcidae (A. Valdez-Mondragón, B.A. Huber, D. Dimitrov, unpubl. data).

\title{
Material and methods
}

Most of the material studied herein was collected during a recent expedition to the Malay Peninsula (Feb.-Mar. 2015). This material is currently deposited at Zoologisches Forschungsmuseum Alexander Koenig, Bonn (ZFMK) and Princess Maha Chakri Sirinthorn Natural History Museum, Prince of Songkla University, Hat Yai (PSUZC). Further material studied is deposited at the following institutions: Museo Argentino de Ciencias Naturales, Buenos Aires (MACN); Muséum national d'Histoire naturelle, Paris (MNHN); Rijksmuseum van Natuurlijke Historie, Naturalis, Leiden (RMNH); Forschungsinstitut und Naturmuseum Senckenberg, Frankfurt (SMF).

Species descriptions are arranged from north to south. Methods and terminology are as in recent revisions (Huber 2011, 2013). Measurements are in mm unless otherwise stated. Eye measurements are $\pm 5 \mu \mathrm{m}$. Epigyna were cleared in warm $\mathrm{NaOH}$ solution and stained with chlorazol black. For SEM photos, specimens were dried in HMDS (Brown 1993) and photographed with a Hitachi S-2460 scanning electron microscope. The distribution map was generated with ArcMap 10.0. Locality coordinates are in round brackets when copied from labels, in square brackets when originating from some other source (such as Google Earth). The following abbreviations are used: ALE: anterior lateral eyes; ALS: anterior lateral spinnerets; AME: anterior median eyes; a.s.l.: above sea level; L/d: length/diameter; PME: posterior median eyes.

\section{Results}

\author{
Class Arachnida Cuvier, 1812 \\ Order Araneae Clerck, 1757 \\ Family Pholcidae C.L. Koch, 1851
}

Genus Savarna Huber, 2005

Savarna Huber, 2005: 76-77. Type species: S. thaleban Huber, 2005.

\section{Diagnosis}

Medium sized ( $\sim 2-3 \mathrm{~mm}$ total body length), six-eyed spiders, with round to oval abdomen and relatively long legs (Figs 2-13). Distinguished from similar genera (Spermophora Hentz, 1841; Khorata Huber, 2005; Aetana Huber, 2005) by having the long male palpal trochanter apophysis uniquely attached to the femur (Figs 15, 21, 48, 57, 66, 82), and by the male cheliceral armature (laterally projecting proximal 
cheliceral apophyses and no further modification; Figs 16, 45, 55, 63, 83). It furthermore differs from Spermophora by the absence of epigynal pockets, the absence of epiandrous spigots (Figs 26, 52, 71) and the reduction of AMS spigots to two (Figs 24, 53, 61, 70).

\section{Amendments to original description}

Male distance PME-PME 185-255 $\mu \mathrm{m}$. Male clypeus either with brushes of hairs (S. kraburiensis; Fig. 45), with paired processes at rim (S. kaeo sp. nov.; S. thaleban; S. miser; Figs 20, 55), or with median process at rim (S. tessellata; Fig. 63). Abdomen consistently with dark and white marks (the monochromous abdomen of the male holotype of $S$. baso - dating from 1913 - is probably an artifact). Male leg $1 \sim 9-10 \times$ body length; tibia 2 either slightly longer than tibia 4 or of same length. Legs either without spines (S. thaleban; S. miser), with spines on femora 1 (S. kraburiensis; S. tessellata), or with spines on femora 1-2 and tibiae 1-3 (S. kaeo sp. nov.). Male tibiae with higher than usual density of short vertical hairs. Retrolateral trichobothrium on male tibia 1 at $7-9 \%$ of tibia 1 length. Tarsus 4 with single ventral row of comb-hairs (Figs 51, 62, 69). Male gonopore without epiandrous spigots (all species examined except $S$. miser; Figs $26,52,71$ ). ALS with only two spigots each (all species examined except $S$. miser; Figs 24, 53, 61, 70).

\section{Monophyly and relationships}

Previously, the monophyly of Savarna was supported mainly by two unique morphological characters, the modifications of the male chelicerae and of the male palpal trochanter (Huber 2005). Preliminary analyses of molecular data of all known species (A. Valdez-Mondragón, B.A. Huber, D. Dimitrov, unpubl. data) strongly support the monophyly of Savarna.

The single ventral row of comb-hairs on the fourth tarsus places the genus in Pholcinae ( $c f$. Huber \& Fleckenstein 2008). The morphology of the comb-hairs ('Belisana-type' sensu Huber \& Fleckenstein 2008) suggests the genus is not part of the Pholcus group of genera. Preliminary analyses of molecular data strongly support this 'basal' position in Pholcinae. Detailed relationships with other genera among 'basal' Pholcinae remain obscure. The absence of epiandrous spigots is rare in Pholcinae and is otherwise known only in Khorata Huber, 2005 (B.A. Huber, unpubl. data on three species), in Spermophorides Wunderlich, 1992 (B.A. Huber, unpubl. data on one species), and in two undescribed species of unknown affinity from Borneo (B.A. Huber, unpubl. data). Our preliminary molecular analyses do weakly support a close relationship among some of these taxa.

\section{Natural history}

Even though Savarna spiders also occur outside caves, all known localities are closely associated with limestone caves. Both inside and outside the caves, the spiders build domed webs close to the ground with at least one side of the web attached to the rock surface. Web diameter ranges from about 10 to 25 $\mathrm{cm}$. When disturbed, the spiders vibrate; if disturbance continues or is strong, they drop to the ground and remain motionless for a while ( $c f$. Fig. 7). Egg-sacs are covered by a sparse layer of barely visible silk and contain about 20-30 eggs ( $c f$. Fig. 13). For data on individual species, see descriptions below.

\section{Composition}

The genus now includes five species, all of which are treated below.

\section{Distribution}

Savarna appears to be restricted to southern Thailand, mainland Malaysia, and Sumatra (Fig. 1; but see Addendum). 


\section{Key to species}

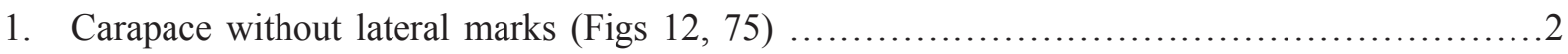

- Carapace with dark lateral marks (Figs 2, 6) .................................................

2. Male clypeus with single median process (Fig. 63); genital bulb with two processes in opposing directions (Fig. 65); male palpal tibia unusually slender (Huber 2005: fig. 138); epigynum posterior margin projecting medially (Figs 32, 72) .....S. tessellata (Simon, 1901)

- Male clypeus with pair of rounded processes at rim (similar to S. kaeo sp. nov., cf. Fig. 20); bulb with single process (Figs 79, 81); male palpal tibia 'normal', i.e., not unusually slender (Fig. 81); epigynum posterior margin without median projection (Figs 34, 84) ...S. miser (Bristowe, 1952)

3. Male genital bulb with two long processes in opposing directions (Fig. 50); epigynum with prominent median process (Fig. 54) ...........S. kraburiensis Wongprom \& Wiwatwitaya, 2015

- Male genital bulb with only one process or with much shorter processes (Figs 14, 22, 60); epigynum without median process (Figs 28-31)

4. Male palpal procursus strongly curved (Huber 2005: fig. 132); male clypeus with very indistinct pair of lateral processes at rim (Fig. 55); epigynum evenly curved, without lateral posterior humps (Figs 30-31)

S. thaleban Huber, 2005

- Male palpal procursus weakly curved (Fig. 15); male clypeus with distinct pair of lateral processes at rim provided with hair brushes (Fig. 20); epigynum with pair of lateral humps near posterior rim (Figs 27-29)

S. kaeo sp. nov.

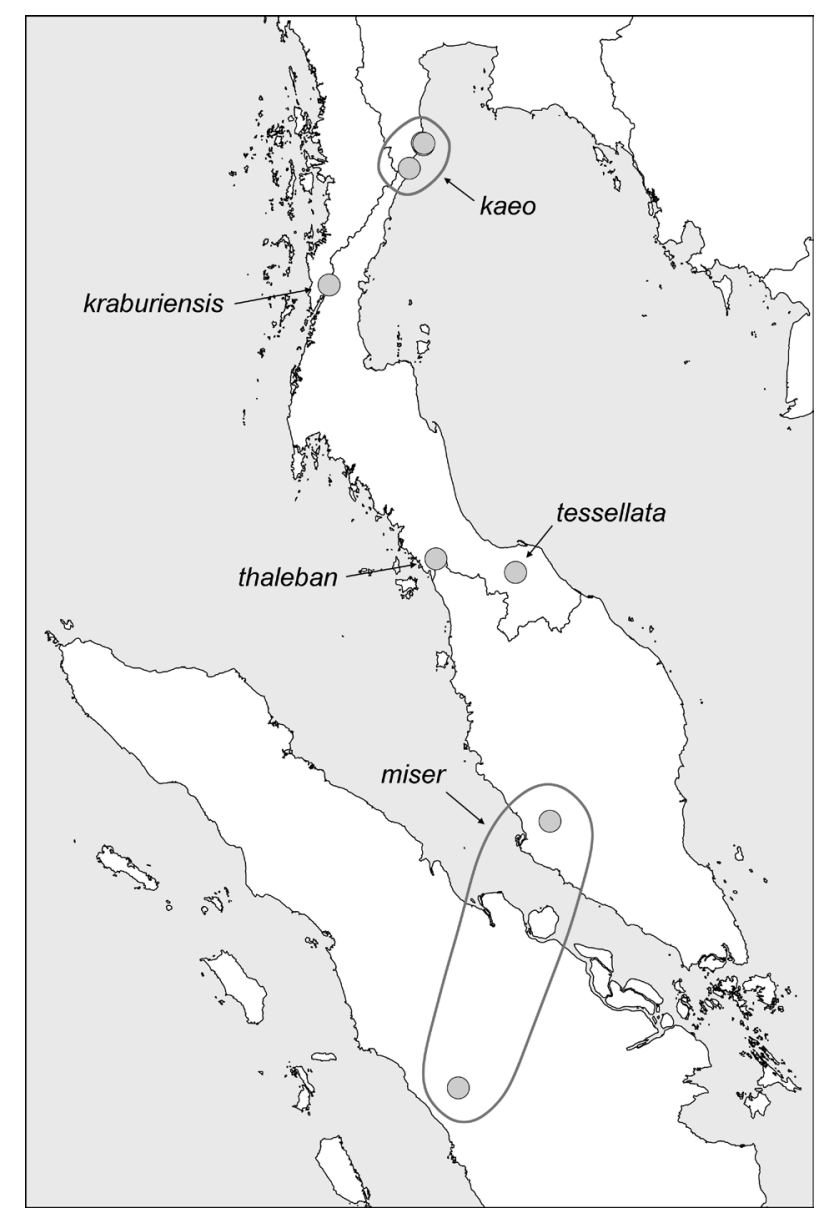

Fig 1. Known distribution of the genus Savarna; but see Addendum. 


\section{Savarna kaeo sp. nov. urn:1sid:zoobank.org:act:2F4E832E-5406-427A-B67F-C503EBBFB94D}

Figs 2-4, 14-29, 36-37

\section{Diagnosis}

Easily distinguished from known congeners by morphology of male palp (shapes of procursus and bulbal process; Figs 14-15), and by female external and internal genitalia (epigynal plate more or less divided medially, without median process as in S. kraburiensis; Figs 17, 27-29). From S. miser and S. tessellata also distinguished by distinct black marks laterally on carapace (Figs 2-4).

\section{Etymology}

The species name is derived from the type locality; noun in apposition.

\section{Material examined}

Holotype

THAILAND: đ̊, Prachuap Khiri Khan, Khao Sam Roi Yot National Park, Tham Kaeo $\left(12^{\circ} 12.2^{\prime}\right.$ N, 99 59.5' E), 60 m a.s.1., in and around cave, 14 Mar. 2015, B.A. Huber \& B. Petcharad leg., ZFMK (Ar 12983).

\section{Paratypes}

THAILAND: $7 \hat{\jmath}$, 17 우, same data as holotype, ZFMK (Ar 12984, 12985); $3 \hat{\jmath}, 3$ 우, same data as holotype, PSUZC.

\section{Other material}

THAILAND: Prachuap Khiri Khan, Khao Sam Roi Yot National Park, Tham Kaeo, 3 오, 2 juvs,

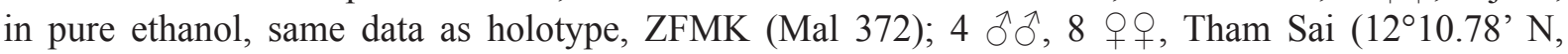
$100^{\circ} 00.44^{\prime}$ E), $80 \mathrm{~m}$ a.s.1., in and around cave, 14 Mar. 2015, B.A. Huber \& B. Petcharad leg., ZFMK (Ar 12986, 12987); 4 우, 2 juvs, in pure ethanol, same data as preceding, in cave, ZFMK (Mal 370); 1 \&, 2 juvs, in pure ethanol, same data as preceding, outside cave, ZFMK (Mal 371); $1 \hat{\jmath}, 1$, , near Tham Phraya Nakhon $\left(12^{\circ} 12.0^{\prime} \mathrm{N}, 100^{\circ} 00.8^{\prime} \mathrm{E}\right), 40 \mathrm{~m}$ a.s.1., among rocks in forest near cave, 14 Mar. 2015, B.A. Huber \& B. Petcharad leg., ZFMK (Ar 12988); 4 §ิ ô, 4 우, Khao Sam Roi Yot, among rocks and stones, 8 Dec. 1990, C.L. Deeleman-Reinhold leg., RMNH. $-4 \delta^{\lambda} \sigma^{\lambda}, 3$ 우, Reclining Buddha Cave (11 ${ }^{\circ} 51.84^{\prime}$ N, $99^{\circ} 49.40^{\prime}$ E), 70 m a.s.1., in cave, 13 Mar. 2015, B.A. Huber \& B. Petcharad leg., ZFMK (Ar 12989, 12990); 2 우, in pure ethanol, same data as preceding, ZFMK (Mal 366).

\section{Description}

Male (holotype)

MeAsurements. Total body length 2.7, carapace width 1.1. Leg 1: $24.1(6.2+0.4+5.9+9.4+2.2)$, tibia 2: 3.7, tibia 3: 2.6, tibia 4: 3.6; tibia 1 L/d: 56. Distance PME-PME $200 \mu \mathrm{m}$, diameter PME $95 \mu \mathrm{m}$, distance PME-ALE $35 \mu \mathrm{m}$; AME absent.

CoLOR. Carapace pale ochre, with wide dark lateral margins; ocular area and clypeus also dark brown; sternum black; legs light ochre, with darker rings on femora (subdistally) and tibiae (proximally); abdomen gray, with dark subcuticular marks lying above deeper white marks, with distinct ventral pattern consisting of three interconnected black marks.

Body. Habitus as in Fig. 2; ocular area elevated, each triad on short hump directed toward lateral; carapace with deep median furrow (Fig. 19); clypeus with pair of rounded processes at rim provided with strong and long hairs (Figs 19-20); sternum wider than long $(0.72 / 0.48)$, unmodified. Chelicerae as in Fig. 16, with pair of lateral processes directed slightly toward posterior; without stridulatory ridges. ALS as in female (cf. Fig. 24). Gonopore without epiandrous spigots (Fig. 26). 
PaLPS. As in Figs 14-15; coxa unmodified; trochanter with small dorsal process and distinctive ventral apophysis proximally attached to femur (Fig. 21); ventral side of femur apparently largely membranous; tarsal organ capsulate (Fig. 25); procursus distally complex (Figs 22-23), with distinctive membranous and sclerotized elements; bulb with large proximal sclerite, with single complex process apparently containing sperm duct (Figs 14, 22).
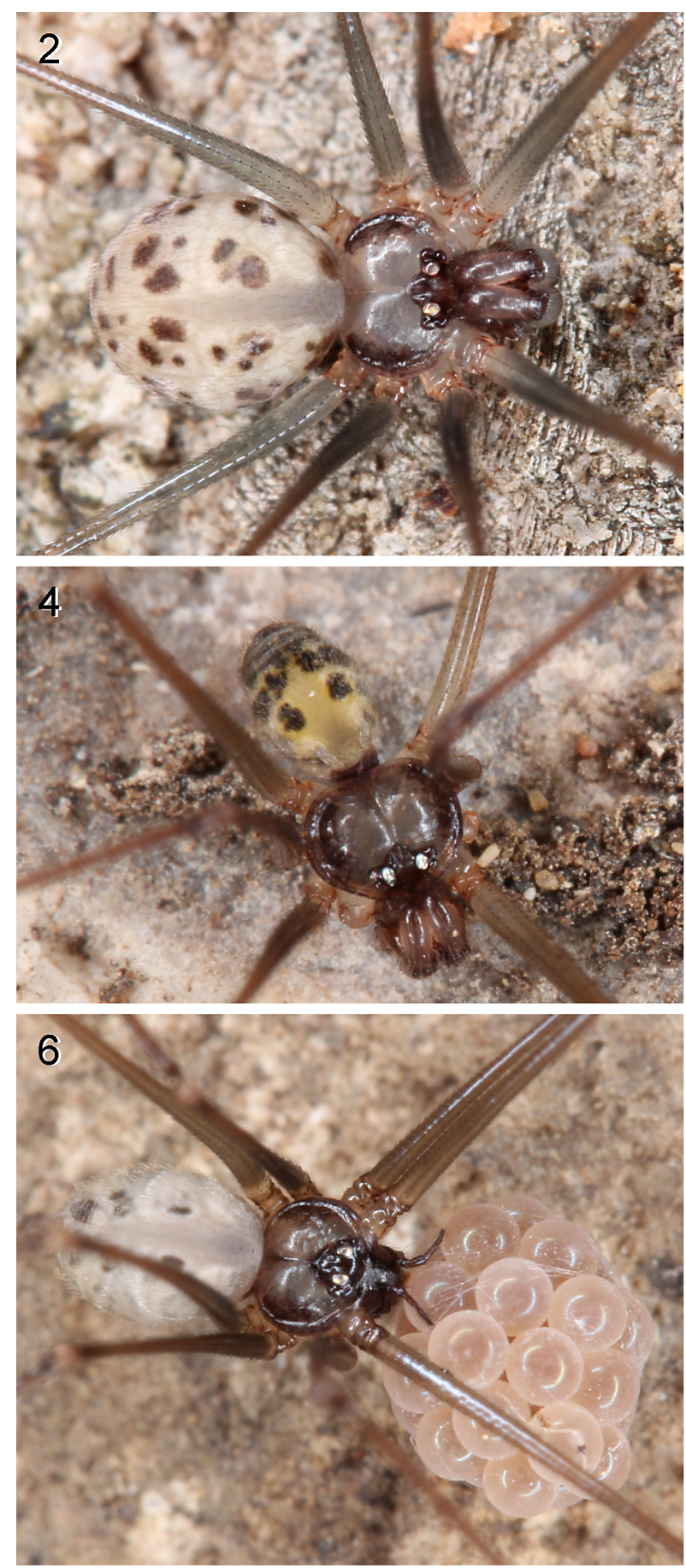
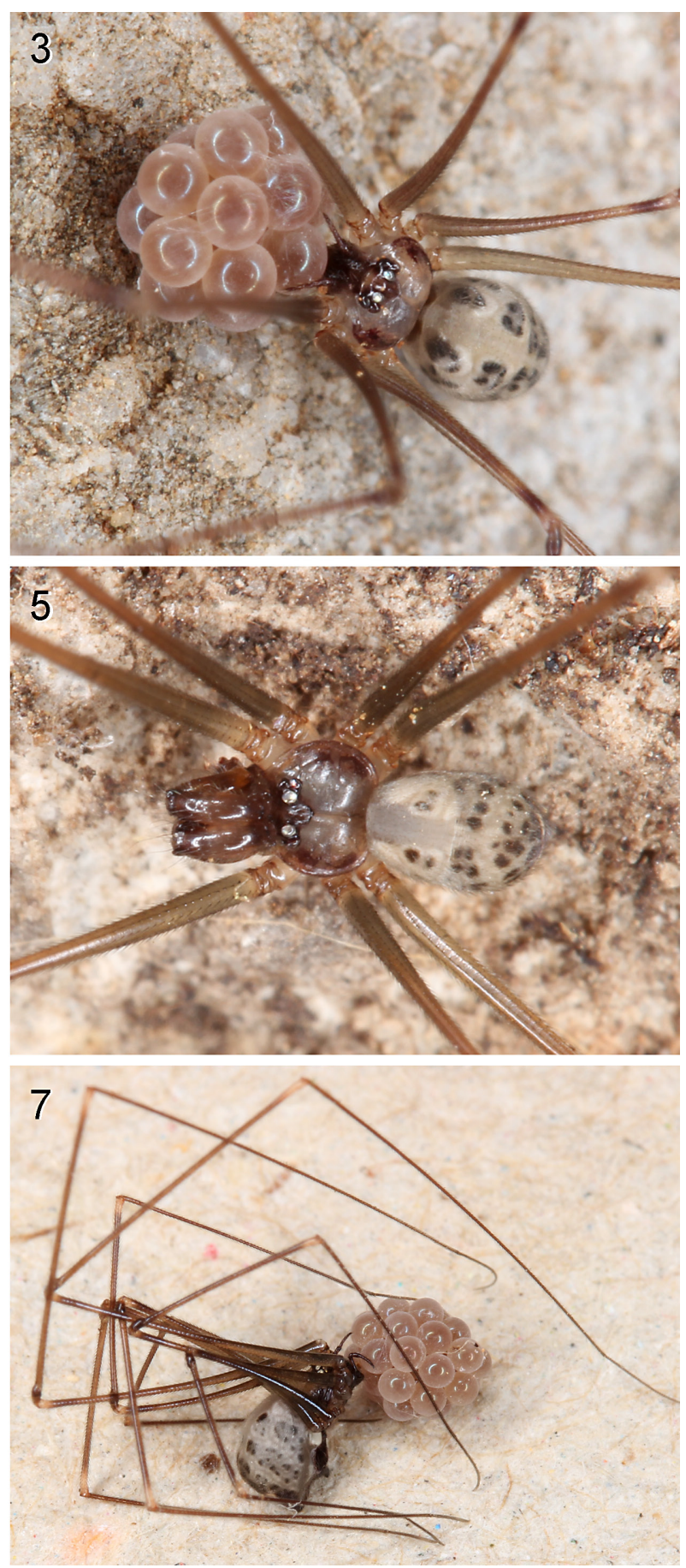

Figs 2-7. Live specimens. - 2-4. Savarna kaeo sp. nov. $\widehat{\partial}$ ô from Reclining Buddha Cave and from Tham Sai $(2,4)$; $q$ with eggsac from Tham Sai (3). - 5-7. S. kraburiensis Wongprom \& Wiwatwitaya, 2015. $\lambda, q$ with eggsac, and $q$ with eggsac after dropping to the ground; all from Tham Phra Kayang. 
LEGS. With short spines in single ventral rows on femora 1-3 and tibiae 1-2 (femur 1: 40 on distal half; femur 2: $\sim 20$ on distal half; femur 3: 10 distally; tibia 1: $\sim 80$ over entire length; tibia 2: $\sim 50$ over entire length); with vertical hairs in higher than usual density on all tibiae (especially tibiae 2-4); without curved hairs; retrolateral trichobothrium on tibia 1 at $8 \%$; prolateral trichobothrium absent on tibia 1 , present on other tibiae; tarsal pseudosegments indistinct, only about 10 visible distally on tarsus 1 .
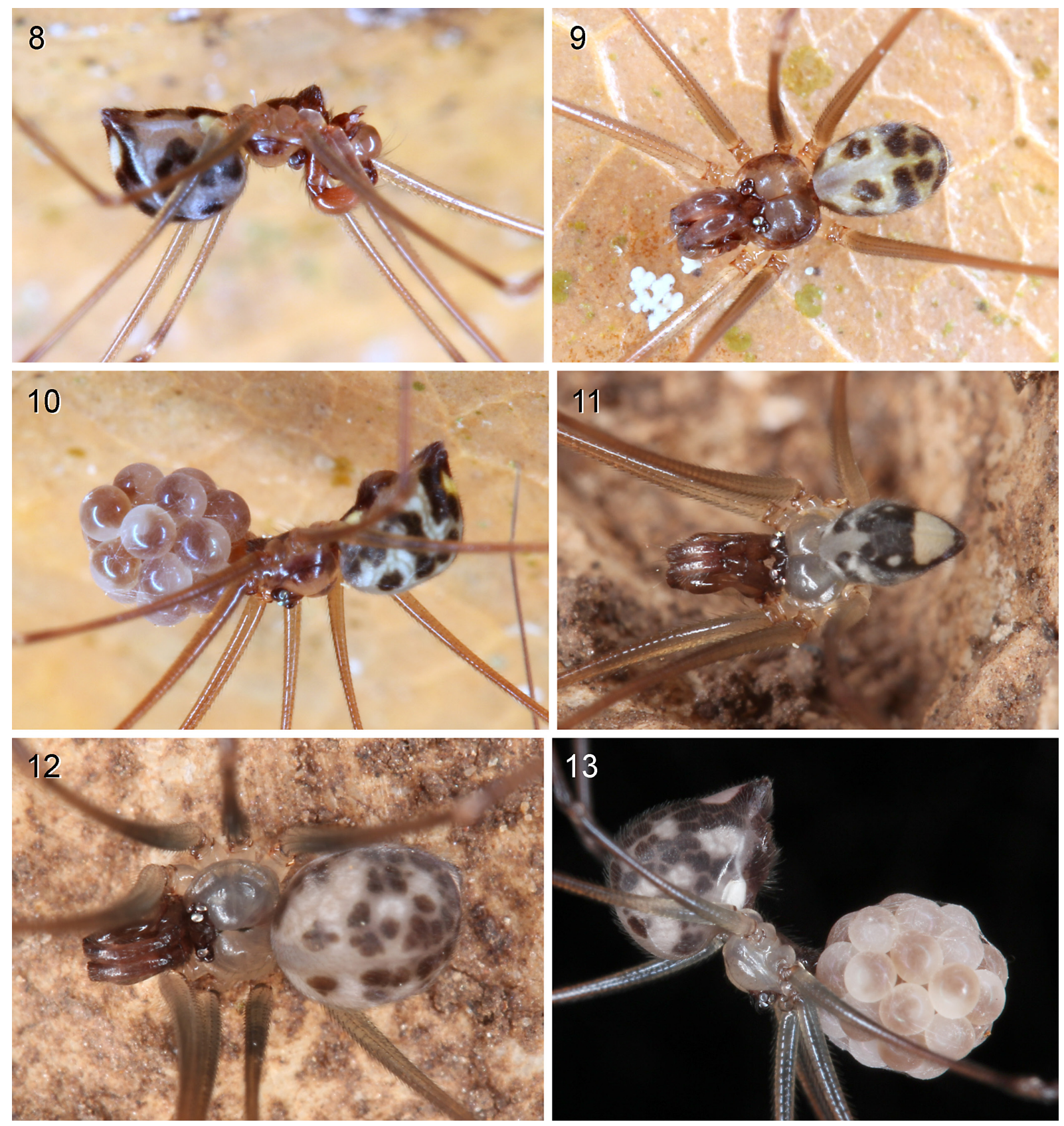

Figs 8-13. Live specimens. - 8-10. Savarna thaleban Huber, 2005. ठิ $\widehat{d}$ and $q$ with eggsac; all from Thaleban National Park. - 11-13. S. tessellata (Simon, 1901). $\partial^{\lambda}$ and $q$ with eggsac; all from Tham Meud. 
Male (variation)

Numbers of spines on legs variable, femur 3 spines absent in most males; small males with fewer and thinner spines. Tibia 1 in 16 other males: 4.9-6.4 (mean 5.6).

\section{Female}

In general similar to male (Fig. 3); eye triads closer together (PME-PME distance: $140 \mu \mathrm{m}$ ); clypeus unmodified; legs without spines and with usual low number of vertical hairs. Tibia 1 in 24 females: 4.0-5.5 (mean 4.8). Epigynum slightly protruding toward posterior (Fig. 29), with wide transversal sclerotized plate with rounded humps laterally (Figs 17, 27-28), plate more or less divided medially (Figs 28, 36; variable even within localities); internal genitalia as in Figs 18 and 37. ALS with only two spigots each (Fig. 24).

\section{Natural history}

Spiders were found both inside caves (twilight zone) and outside caves if large rocks provided sufficient shade (Tham Kaeo; Tham Phraya Nakhon). When disturbed, the spiders first vibrated, and then dropped to the ground, remaining motionless.

\section{Distribution}

Known from several localities in southern Thailand (Fig. 1).

Savarna kraburiensis Wongprom \& Wiwatwitaya, 2015

Figs 5-7, 44-54

Savarna kraburiensis Wongprom \& Wiwatwitaya, 2015: 2-5, figs 1-2 (ぷ+ + ).

\section{Diagnosis}

Easily distinguished from known congeners by morphology of male palp (bulb with two long processes; tip of procursus; Figs 49-50), and by female external and internal genitalia (epigynal plate with median process; Fig. 54). From S. kaeo sp. nov. also distinguished by absence of pair of processes on male clypeus (Figs 44-45); from $S$. tessellata and $S$. miser also distinguished by black marks laterally on carapace (Figs 5-6).

\section{Type material}

THAILAND: $\hat{\jmath}$, holotype; $1 \hat{\delta}, 2$ 9 , , paratypes; Ranong, Kraburi District, Phra Kha Yang Cave $\left(10^{\circ} 19.57^{\prime} \mathrm{N}, 98^{\circ} 45.91^{\prime}\right.$ E), 6 m a.s.1., 28 Oct. 2014, P. Wongprom leg., Thailand Natural History Museum, Pathum Thani, not examined.

\section{Material examined}

THAILAND: 8 $\widehat{\partial}, 5$ 우, Ranong, Kraburi District, Tham Phra Kayang [=Phra Kha Yang Cave] $\left(10^{\circ} 19.54^{\prime} \mathrm{N}, 9^{\circ} 45.88^{\prime} \mathrm{E}\right), 10-50 \mathrm{~m}$ a.s.l., in cave and in forest above cave, 13 Mar. 2015, B.A. Huber \& B. Petcharad leg., ZFMK (Ar 12991, 12992); 3 $\widehat{\jmath}, 3$ 웅, same data (PSUZC); 4 우, 2 juvs, in pure ethanol, same data, ZFMK (Mal 365).

\section{Amendments to original description}

Male clypeus without processes but with strong hair brushes not present in female (Figs 44-46). Male gonopore without epiandrous spigots (Fig. 52). Male and female ALS with only two spigots each (Fig. 53). In the palp illustrated in the original description (Wongprom \& Wiwatwitaya 2015: fig. 1a) the bulb is rotated about $180^{\circ}$ from its natural position. In the natural position, the long pointed process is directed in the opposite direction and the proximal bulbal sclerite is visible in prolateral view. Spines 
on male legs sometimes absent, sometimes present (each femur 1 with two ventral rows of up to $\sim 25$ spines each); tibia $1 \mathrm{~L} / \mathrm{d}$ : 53; prolateral trichobothrium absent on tibia 1, present on other tibiae; male and female tarsus 4 with single row of ventral comb-hairs (Fig. 51). Tibia 1 in 10 males: 5.7-6.8 (mean: 6.3); in 5 females: 4.7-5.6 (mean 5.3).

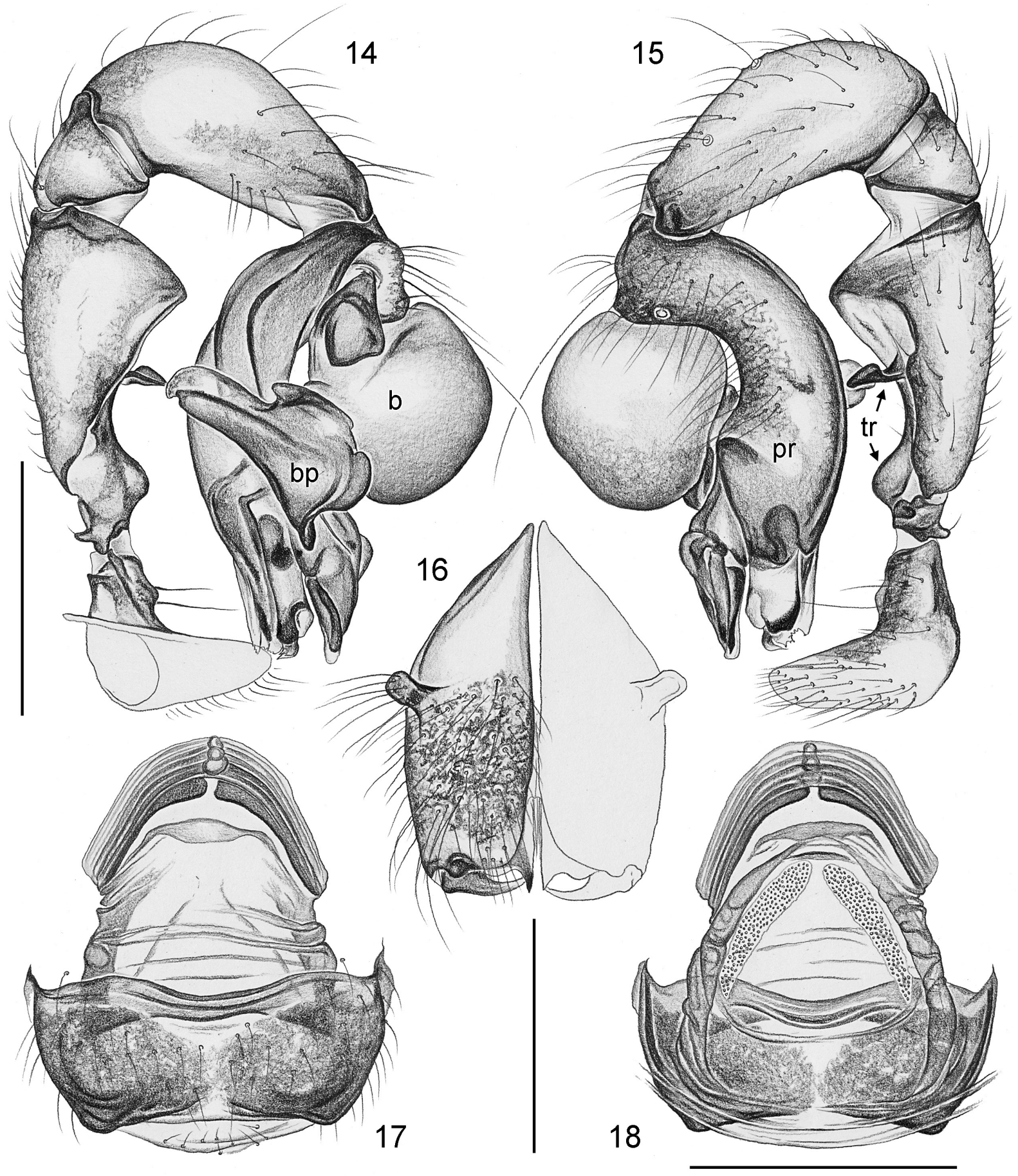

Figs 14-18. Savarna kaeo sp. nov. 14-15. Left male palp, prolateral and retrolateral views $(b=$ genital bulb; $\mathrm{bp}=$ bulbal process; $\mathrm{pr}=$ procursus; $\mathrm{tr}=$ trochanter). 16. Male chelicerae, frontal view. 17-18. Cleared female genitalia, ventral and dorsal views. Scale bars: $16=0.3 \mathrm{~mm} ; 14-15,17-18=0.5 \mathrm{~mm}$. 

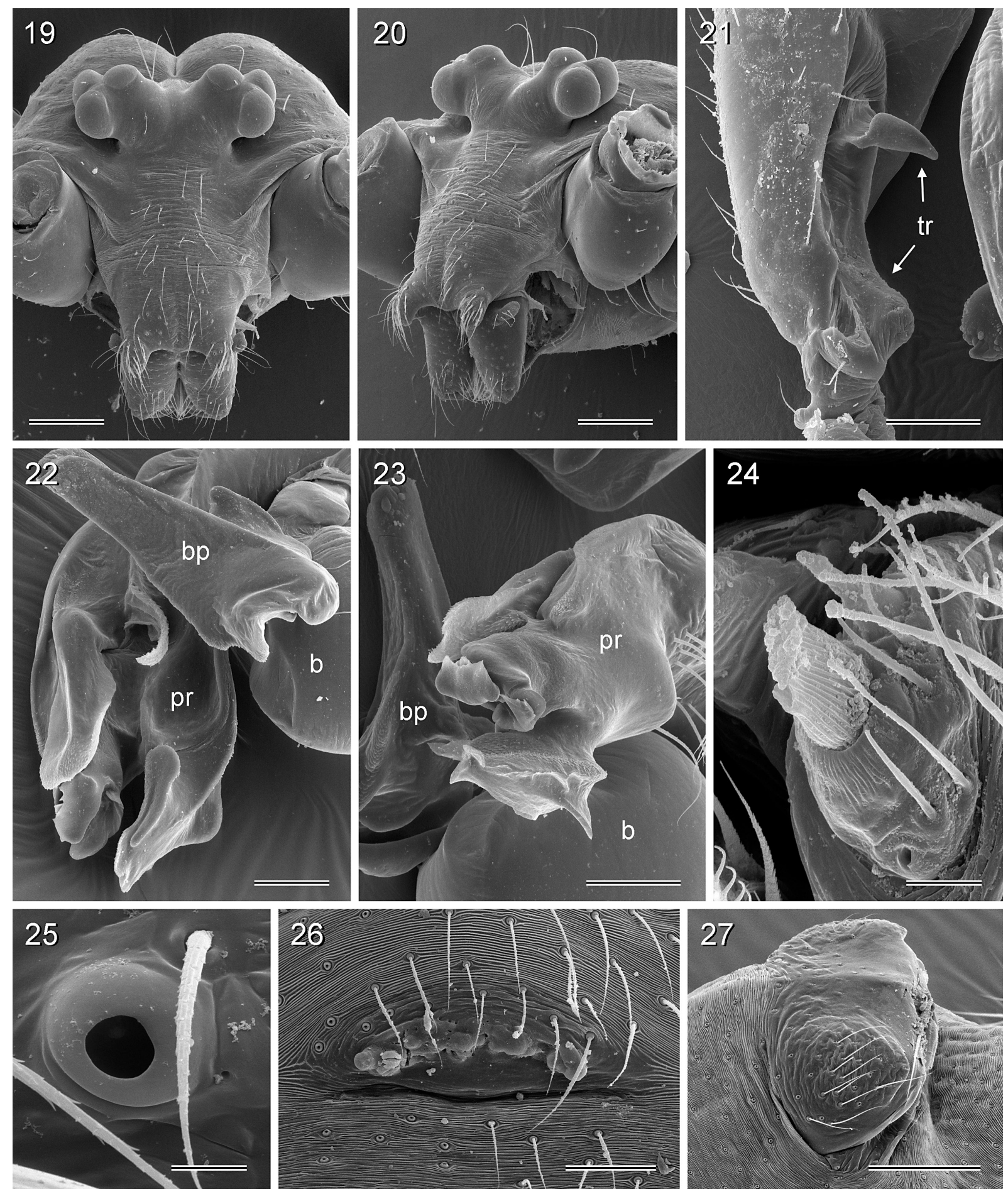

Figs 19-27. Savarna kaeo sp. nov. 19-20. Male prosoma, frontal and oblique frontal views. 21. Right male palpal trochanter (tr) and femur, retrolateral view. 22. Left procursus (pr) and bulbal process (bp), prolatero-distal view $(b=$ bulb). 23. Right procursus (pr) and bulbal process (bp), retrolatero-distal view $(b=$ bulb). 24. Female ALS. 25. Male palpal tarsal organ. 26. Male gonopore. 27. Epigynum, ventrolateral view. Scale bars: $24-25=10 \mu \mathrm{m} ; 26=80 \mu \mathrm{m} ; 21-23=100 \mu \mathrm{m} ; 19-20,27=200 \mu \mathrm{m}$. 


\section{Natural history}

Spiders were found both inside and outside the cave, in domed webs of $\sim 20 \mathrm{~cm}$ diameter. In the cave, they only occurred in the twilight zone. Outside the cave, they were found to be most abundant in the small forest above the cave. When lightly disturbed, the spiders vibrated in their webs; when disturbed more strongly, spiders dropped to the ground, remaining motionless (cf. Fig. 7).

\section{Distribution}

Known only from the type locality (Fig. 1).

Savarna thaleban Huber, 2005

Figs 8-10, 30-31, 42-43, 55-62

Savarna thaleban Huber, 2005: 77, figs 124-126, 131-134 (ぷ゚).

\section{Diagnosis}

Easily distinguished from known congeners by morphology of male palp (shape of bulbal apophysis; tip of procursus; figs 131-132 in Huber 2005), and by female external and internal genitalia (epigynal plate without median or lateral processes, posterior margin evenly curved; pore plates oval, not contiguous; Figs 30-31, 42-43); from $S$. tessellata and S. miser also distinguished by black marks laterally on carapace (Fig. 9).

\section{Material examined}

\section{Holotype}

THAILAND: ${ }^{\top}$, Satun Province, Thale Ban National Park ( $\left(6^{\circ} 42.5^{\prime} \mathrm{N}, 100^{\circ} 10^{\prime} \mathrm{E}\right), 270 \mathrm{~m}$ a.s.1., $15-18$ Oct. 2003, ATOL Expedition 2003 leg., MACN, examined (Huber 2005).

\section{Other material}

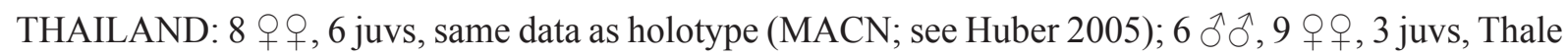
Ban National Park $\left(6^{\circ} 43.58^{\prime} \mathrm{N}, 100^{\circ} 09.74^{\prime} \mathrm{E}\right)$, forest and cave entrance, near ground among rocks,

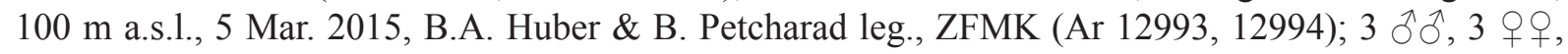
same data (PSUZC); 1 ふै, 1 + 2 juvs, in pure ethanol, same data, ZFMK (Mal 326).

\section{Amendments to original description}

Male clypeus with pair of small lateral processes at rim (Fig. 55). Male gonopore without epiandrous spigots. Male and female ALS with only two spigots each (Fig. 61). In the palp illustrated in the original description (Huber 2005: figs 131-132), the bulb is rotated about $180^{\circ}$ from its natural position. In the natural position, the long bulbal process is directed in the opposite direction and the proximal bulbal sclerite is visible in prolateral view. All males seen without leg spines; prolateral trichobothrium absent on tibia 1, present on other tibiae; male and female tarsus 4 with single row of ventral comb-hairs (Fig. 62). Tibia 1 in 8 males: 4.5-5.4 (mean: 5.0); in 9 females: 4.2-4.9 (mean 4.5).

\section{Natural history}

All specimens were found in the forest outside a small cave, in domed webs among rocks close to the ground. Spiders were abundant but fled very rapidly, dropping from the web to the ground and becoming essentially invisible.

\section{Distribution}

Known only from the type locality (Fig. 1). 
Savarna tessellata (Simon, 1901)

Figs 11-13, 32-33, 40-41, 63-73

Spermophora tessellata Simon, 1901: 50 (ㅇ).

Savarna tessellata - Huber 2005: 78-79, figs 129-130, 138-140 (ð゙).

\section{Diagnosis}

Easily distinguished from known congeners by median process on male clypeus (Fig. 63), by morphology of male palp (very long and slender tibia; distinctive bulbal processes; tip of procursus; Fig. 65 and figs 138-139 in Huber 2005), and by female external and internal genitalia (epigynal plate with pair of
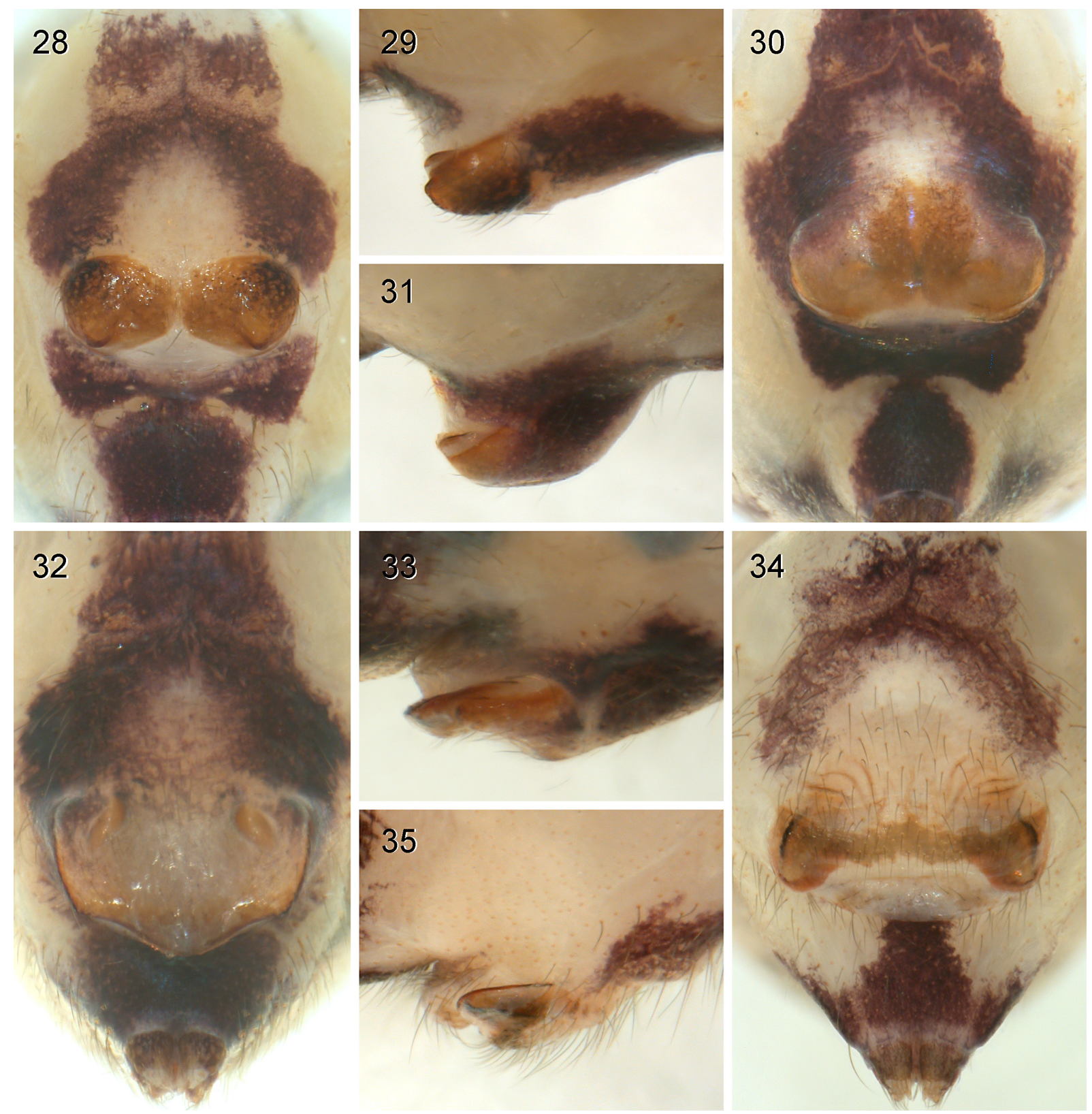

Figs 28-35. Epigyna, ventral and lateral views. - 28-29. Savarna kaeo sp. nov. - 30-31. S. thaleban Huber, 2005. - 32-33. S. tessellata (Simon, 1901). - 34-35. S. miser (Bristowe, 1952). At varying scales. 
lateral oval humps; shape of posterior rim of epigynal plate; large internal sclerite; Figs 32, 40, 72). From most species (except $S$. miser) also distinguished by absence of black marks laterally on carapace (Figs 11-12).

\section{Type material}

THAILAND: $q$, holotype (or +9 , syntypes), “Jalor, Biserat” (probably Yala Province, Wat Kuhapimuk; see below), collected by the Skeat Expedition (1899-1900), not examined (apparently not in MNHN, possibly lost - see Notes below).
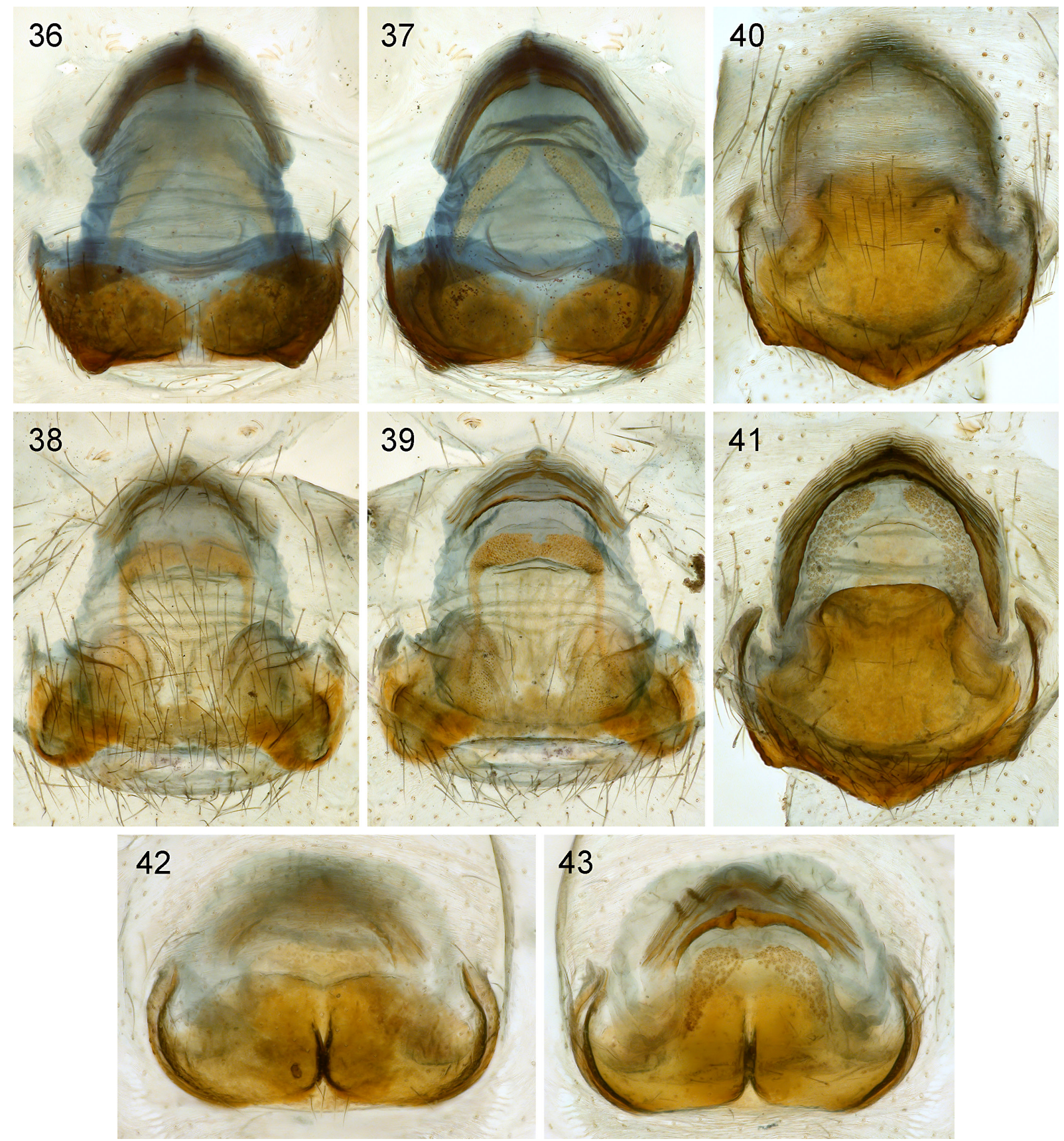

Figs 36-43. Cleared and stained female genitalia, ventral and dorsal views. - 36-37. Savarna kaeo sp. nov. - 38-39. S. miser (Bristowe, 1952). - 40-41. S. tessellata (Simon, 1901). - 42-43. S. thaleban Huber, 2005. At varying scales. 


\section{Material examined}

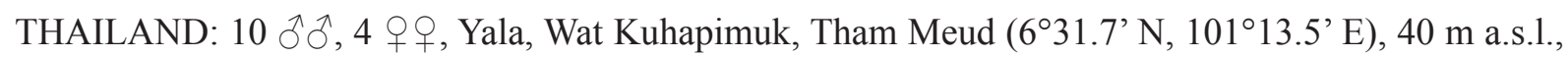
near ground in cave and among rocks outside cave, 4 Mar. 2015, B.A. Huber \& B. Petcharad leg., ZFMK

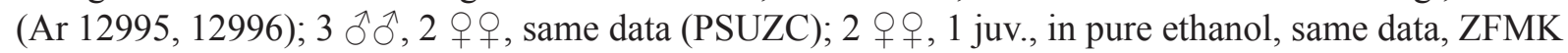
(Mal 322).

\section{Notes on type material and type locality}

The three specimens $(1 \hat{\jmath}, 1$,, 1 juv.) in MNHN redescribed in Huber (2005) may or may not include the female described by Simon (1901). Simon's handwritten label just says "12185 Sp. tessellata E.S. Pen. Malayana (C.M)". In any case, we are now confident that these specimens, as well as the new specimens collected at Wat Kuhapimuk (see below), are in fact conspecific with Simon's described specimen(s). All details of Simon's description fit the newly collected females, and even the distinctive shape of the epigynum (“...in medio depressa, ... utrinque oblique truncata, postice leviter prominula"; Simon 1901: 50) exactly fits the new specimens.

"Jalor, Biserat" was previously erroneously thought to be in Malaysia (Huber 2005). Instead, several lines of evidence suggest that this is in Yala Province (=Jalor in the Pattani Malay language) in southern Thailand. We actually suggest that the type locality is precisely what is today Wat Kuhapimuk, near Yala City. First, Laidlaw's (1900) brief account of the itinerary of the Skeat Expedition shows that "Biserat, a village in a small state called Jalor" was visited on the way between Patani and the Kelantan River in northeastern Malaysia. Yala City is located exactly between Patani (=Pattani) and the Kelantan River. Second, Serat (Pattani Malay language) equals Sap (Thai language), suggesting that the village Ban Tha Sap (Thai for 'village - riverbank - Sap'), located just $2 \mathrm{~km}$ from Wat Kuhapimuk, might be identical to Biserat. Finally, another pholcid species described by Simon (1901) in the same publication (Pholcus diopsis) has the type locality "Gua Glap ("Dark Cave"), Biserat, Jalor" (Simon 1901: 50). We found Pholcus diopsis in the cave Tham Meud at Wat Kuhapimuk. Thus, we assume that what is today called Tham Meud (Thai = Dark Cave) at Wat Kuhapimuk is identical to Simon's Gua Glap (Malay = Dark Cave). Unlike Pholcus diopsis, Savarna tessellata occurs both inside and outside the cave. The original material was possibly collected outside, explaining the absence of a mention of the cave in the original description.

\section{Description}

\section{Male (ZFMK Ar 12995)}

Measurements. Total body length 2.6, carapace width 1.1. Leg 1: $23.2(5.8+0.4+5.8+8.9+2.3)$, tibia 2: 3.5, tibia 3: 2.6, tibia 4: 3.4; tibia 1 L/d: 55. Distance PME-PME $245 \mu \mathrm{m}$, diameter PME $90 \mu \mathrm{m}$, distance PME-ALE $35 \mu \mathrm{m}$; AME absent.

COLOR. Carapace pale ochre, without dark lateral margins; ocular area and clypeus dark brown; sternum black; legs light brown, with darker rings on femora (subdistally) and tibiae (proximally and subdistally); abdomen gray, with dark and white marks, large whitish mark above spinnerets (Fig. 11), with distinct ventral pattern consisting of three interconnected black marks.

Body. Habitus as in Figs 11-12; ocular area elevated, each triad on short hump directed toward lateral; carapace with deep median furrow (Fig. 63); clypeus with long median process at rim (Fig. 63); sternum wider than long, unmodified. Chelicerae with pair of lateral processes (see fig. 140 in Huber 2005). ALS with only two spigots (Fig. 70). Gonopore without epiandrous spigots (Fig. 71).

PaLPs. See figs 138-139 in Huber 2005; trochanter as in Fig. 66; procursus tip as in Figs 67-68; bulb as in Fig. 65. 
LEGs. With short spines on femur 1 ( $\sim 30$ on distal half); with vertical hairs in higher than usual density on all tibiae; without curved hairs; retrolateral trichobothrium on tibia 1 at 7\%; prolateral trichobothrium absent on tibia 1, present on other tibiae; tarsal pseudosegments fairly distinct, $\sim 20$ visible on tarsus 1 .
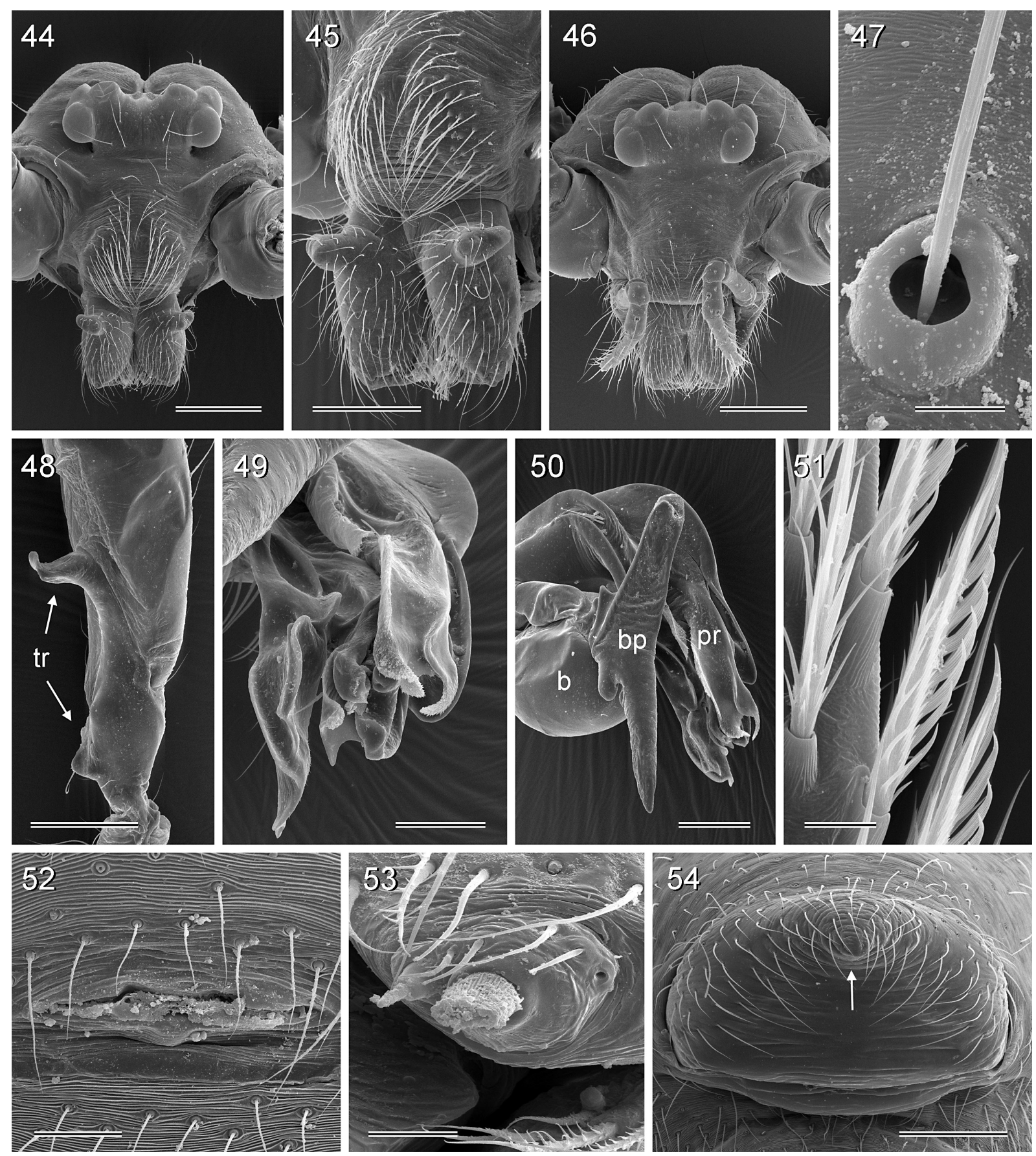

Figs 44-54. Savarna kraburiensis Wongprom \& Wiwatwitaya, 2015. 44. Male prosoma, frontal view. 45. Male clypeus and chelicerae, oblique frontal view. 46. Female prosoma, frontal view. 47. Trichobothrium on female palpal tibia. 48. Right male palpal trochanter (tr) and femur, prolateral view. 49. Right procursus, prolatero-distal view. 50. Right procursus (pr) and genital bulb (b), prolaterodistal view ( $\mathrm{bp}=$ bulbal processes). 51. Comb-hair on female left tarsus 4, prolateral view. 52. Male gonopore. 53. Female ALS. 54. Epigynum, ventral view (arrow points at median process). Scale bars: $47,51=10 \mu \mathrm{m} ; 53=20 \mu \mathrm{m} ; 52=60 \mu \mathrm{m} ; 49=100 \mu \mathrm{m} ; 45,48,50,54=200 \mu \mathrm{m} ; 44,46=300 \mu \mathrm{m}$. 

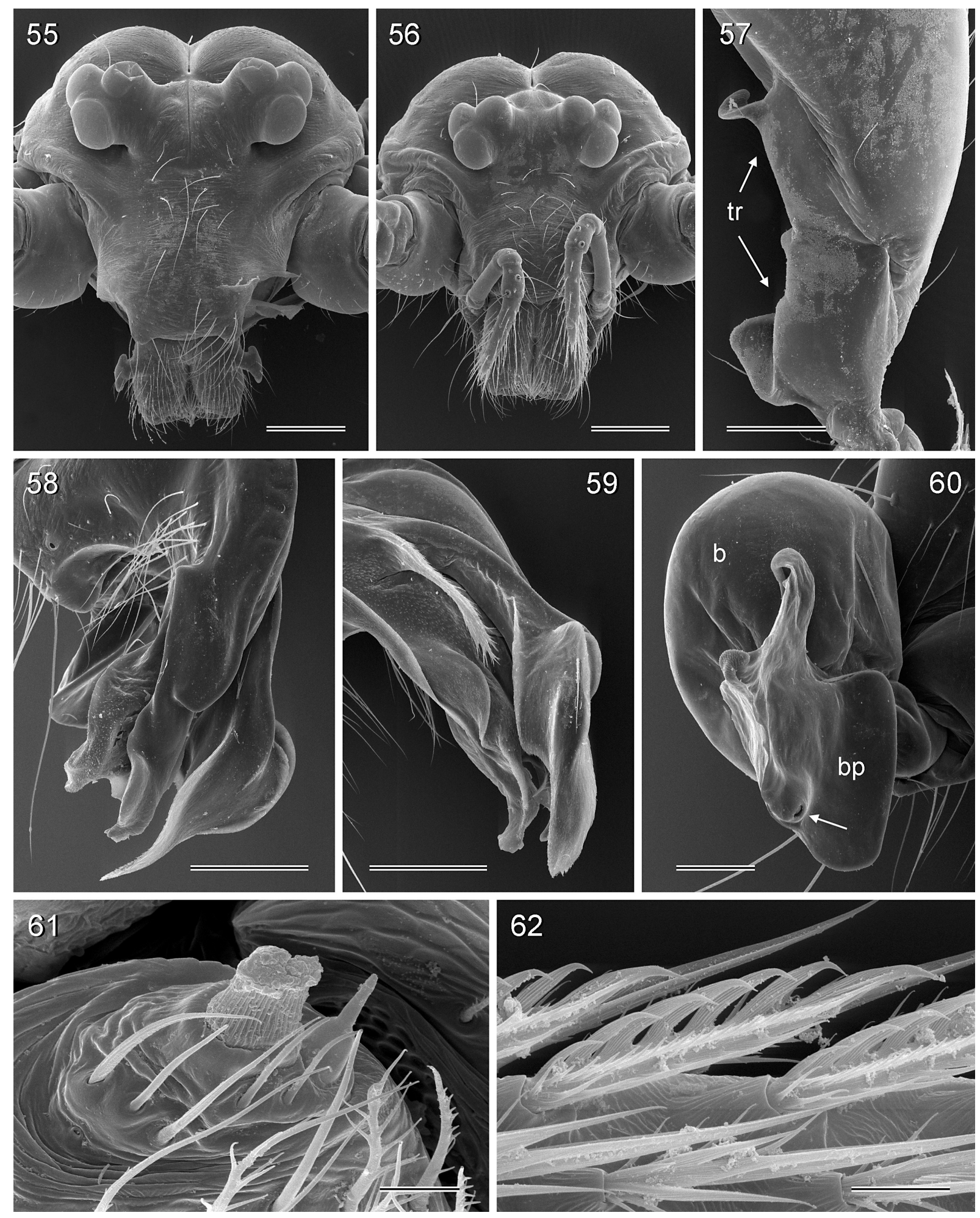

Figs 55-62. Savarna thaleban Huber, 2005. 55-56. Male and female prosomata, frontal views. 57. Right male palpal trochanter (tr), prolateral view. 58. Left procursus, ventro-distal view. 59. Right procursus, prolateral view. 60. Right genital bulb (b) and bulbal process (bp); arrow points at sperm duct opening. 61. Female ALS. 62. Comb-hair on female right tarsus 4, prolateral view. Scale bars: $61-62=10 \mu \mathrm{m}$; $57,60=100 \mu \mathrm{m} ; 55-56,58-59=200 \mu \mathrm{m}$. 

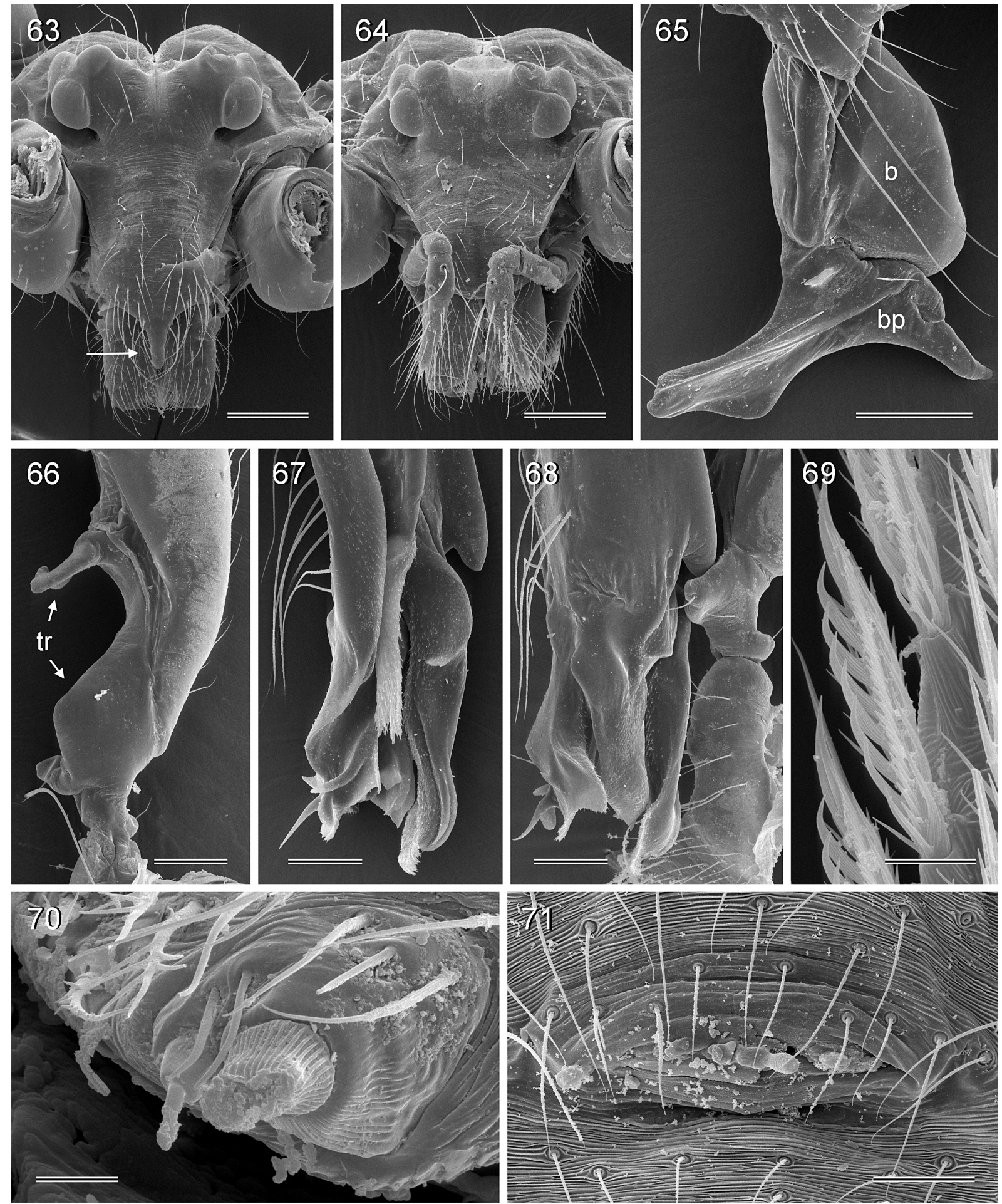

Figs 63-71. Savarna tessellata (Simon, 1901). 63-64. Male and female prosomata, frontal views (arrow points at clypeus process). 65. Left genital bulb (b), retrolateral view (bp $=$ bulbal process). 66. Right male palpal trochanter (tr), prolateral view. 67. Right procursus tip, prolateral view. 68. Left procursus tip, retrolateral view. 69. Comb-hair on male right tarsus 4, prolateral view. 70. Male ALS. 71. Male gonopore. Scale bars: $69-70=10 \mu \mathrm{m} ; 71=50 \mu \mathrm{m} ; 66-68=100 \mu \mathrm{m} ; 63-65=200 \mu \mathrm{m}$. 
Male (variation)

Tibia 1 in 12 other males: 5.4-6.6 (mean: 6.0).

Female (ZFMK Ar 12996)

In general similar to male; eye triads closer together (PME-PME distance: $195 \mu \mathrm{m}$ ); clypeus unmodified (Fig. 64); legs without spines and with usual low number of vertical hairs. Tibia 1 in 5 females: 4.9-5.9 (mean 5.4). Epigynum slightly protruding (Fig. 33), with wider than long epigynal plate with pair of lateral oval humps and distinctive shape of posterior rim (Figs 32, 40, 72); internal genitalia as in Figs 41 and 73, with large internal sclerite and long, anteriorly converging pore plates. ALS as in males.

\section{Natural history}

Both in and outside Tham Meud cave, spiders built domed webs close to the ground, attached to the rocks or rock walls. Inside the cave, spiders were hanging from the apex of the dome while outside the cave they were sitting flat on the rock surface at the border of the web. No specimens were found in deeper parts of the cave (beyond about $20 \mathrm{~m}$ ).

\section{Distribution}

Known only from the type locality (Fig. 1).

Savarna miser (Bristowe, 1952), comb. nov.

Figs 34-35, 38-39, 74-85

Spermophora miser Bristowe, 1952: 704, figs 11-13 ()).

Spermophora baso Roewer, 1963: 229, pl. 18, figs 17-18 (ð). New synonymy.

Spermophora miser - Huber 2005: 85 (considered as incertae sedis).

Savarna baso - Huber 2005: 78, figs 127-128, 135-137 (ð).

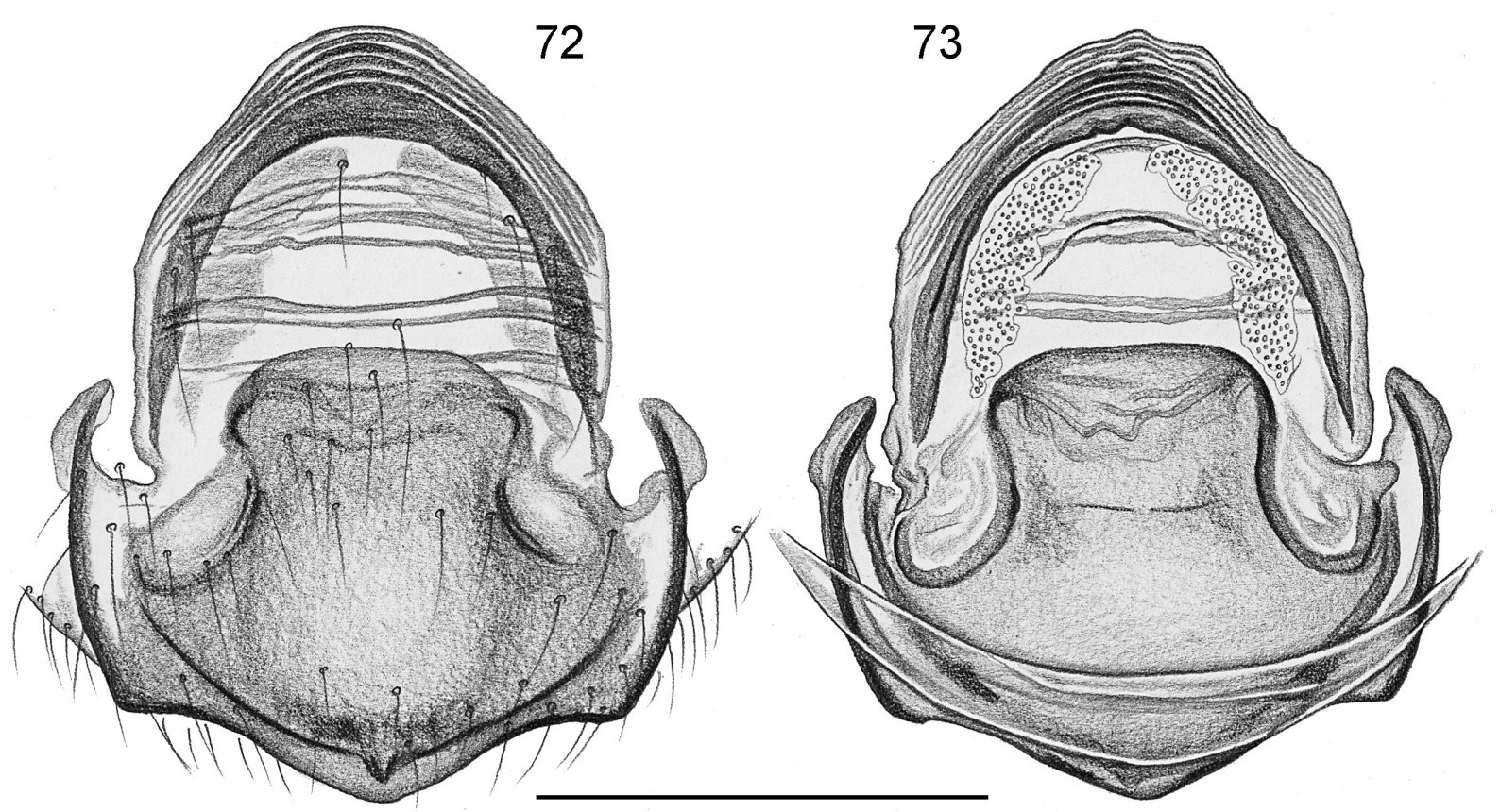

Figs 72-73. Savarna tessellata (Simon, 1901). Cleared female genitalia, ventral and dorsal views. Scale bar: $0.5 \mathrm{~mm}$. 


\section{Justification of synonymy}

The holotype of $S$. baso was compared directly with fresh specimens of $S$. miser originating from the type locality. The males were found to be identical in all relevant genital structures ( $c f$. Figs 77-80).

\section{Diagnosis}

Easily distinguished from known congeners by morphology of male palp (strongly curved ventral trochanter apophysis; shapes of procursus and bulbal process; Figs 81-82), and by female external and internal genitalia (posterior margin of epigynal plate with pair of semicircular extensions; without median process as in S. kraburiensis; pore plates contiguous; Figs 34-35, 38-39, 84-85). From most species (except $S$. tessellata) also distinguihsed by absence of black marks laterally on carapace (Figs 74, 75); from $S$. tessellata also by paired male clypeus apophyses (unpaired in S. tessellata) and less elongated male palpal tibia.

\section{Type material}

Spermophora miser. MALAYSIA: Unknown number of female syntypes and two juveniles, Selangor,

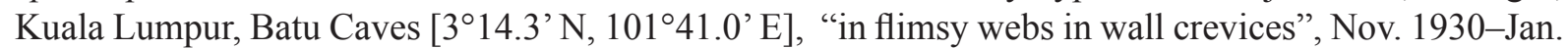
1931, W.S. Bristowe leg., possibly lost (apparently not in the Natural History Museum, London), not examined.

Spermophora baso. INDONESIA: $\widehat{\partial}$, holotype (left palp mounted on slide); 1 q, paratype, prosoma; Sumatra, Sumatera Barat (West Sumatra), cave near Baso [0¹4.9' S, 100²9.0' E], Oct. 1913, E. Jacobson leg., but see Addendum; SMF (RII/13853/122), examined (in 2004 and again for the present study).

\section{Other material examined}

MALAYSIA: $3 \hat{\jmath} \widehat{\jmath}, 3$ 우, in pure ethanol, Selangor, Kuala Lumpur, Batu Caves $\left(3^{\circ} 14.34^{\prime} \mathrm{N}\right.$, $101^{\circ} 40.97^{\prime}$ E), 90 m a.s.1., cave, at day, by hand, 23 Feb. 2015, P. Jäger \& T. Laufs leg. (SMF).

\section{Redescription}

Male (Batu Caves, type locality)

Measurements. Total body length 2.2, carapace width 1.1. Leg 1: $22.2(5.5+0.4+5.4+8.8+2.1)$, all other legs detached; tibia $1 \mathrm{~L} / \mathrm{d}$ : 47. Distance PME-PME $185 \mu \mathrm{m}$, diameter PME $105 \mu \mathrm{m}$, distance PME-ALE $35 \mu \mathrm{m}$; AME absent.

CoLOR. Carapace pale ochre; ocular area and clypeus dark brown; sternum black; legs light brown, with darker rings on femora (subdistally) and tibiae (proximally and subdistally); abdomen pale gray, with dark subcuticular marks lying above deeper white marks, with distinct ventral pattern consisting of three interconnected black marks.

Body. Habitus as in Fig. 74; ocular area elevated, each triad on short hump directed toward lateral; carapace with deep median furrow; clypeus with pair of rounded processes at rim, similar to $S$. kaeo sp. nov. but smaller ( $c f$. Fig. 20); sternum wider than long (0.78/0.54), unmodified. Chelicerae as in Fig. 83, with pair of lateral processes, directed slightly toward posterior; without stridulatory ridges.

PaLPs. As in Figs 81-82; coxa unmodified; trochanter with small retrolateral and ventral processes and distinctive long ventral apophysis, proximally attached to femur, distally strongly curved; procursus distally complex, with distinctive membranous and sclerotized elements; bulb with large proximal sclerite, with single complex process (Fig. 79) apparently containing sperm duct. 
LEGS. Without spines; with vertical hairs in higher than usual density on all tibiae; without curved hairs; retrolateral trichobothrium on tibia 1 at 9\%; prolateral trichobothrium absent on tibia 1, present on other tibiae; tarsal pseudosegments indistinct, about 15 visible distally on tarsus 1 .

Male (variation)

The holotype of S. baso is strongly bleached ( $c f$. figs 127-128 in Huber 2005), but the distinctive male genital structures are indistinguishable from those of males from the type locality (Figs 77-80). In the fresh material from the type locality, all bulbs are rotated away from their natural position, which explains the differences between the palps of S. baso illustrated in Huber (2005) and the palps illustrated herein.
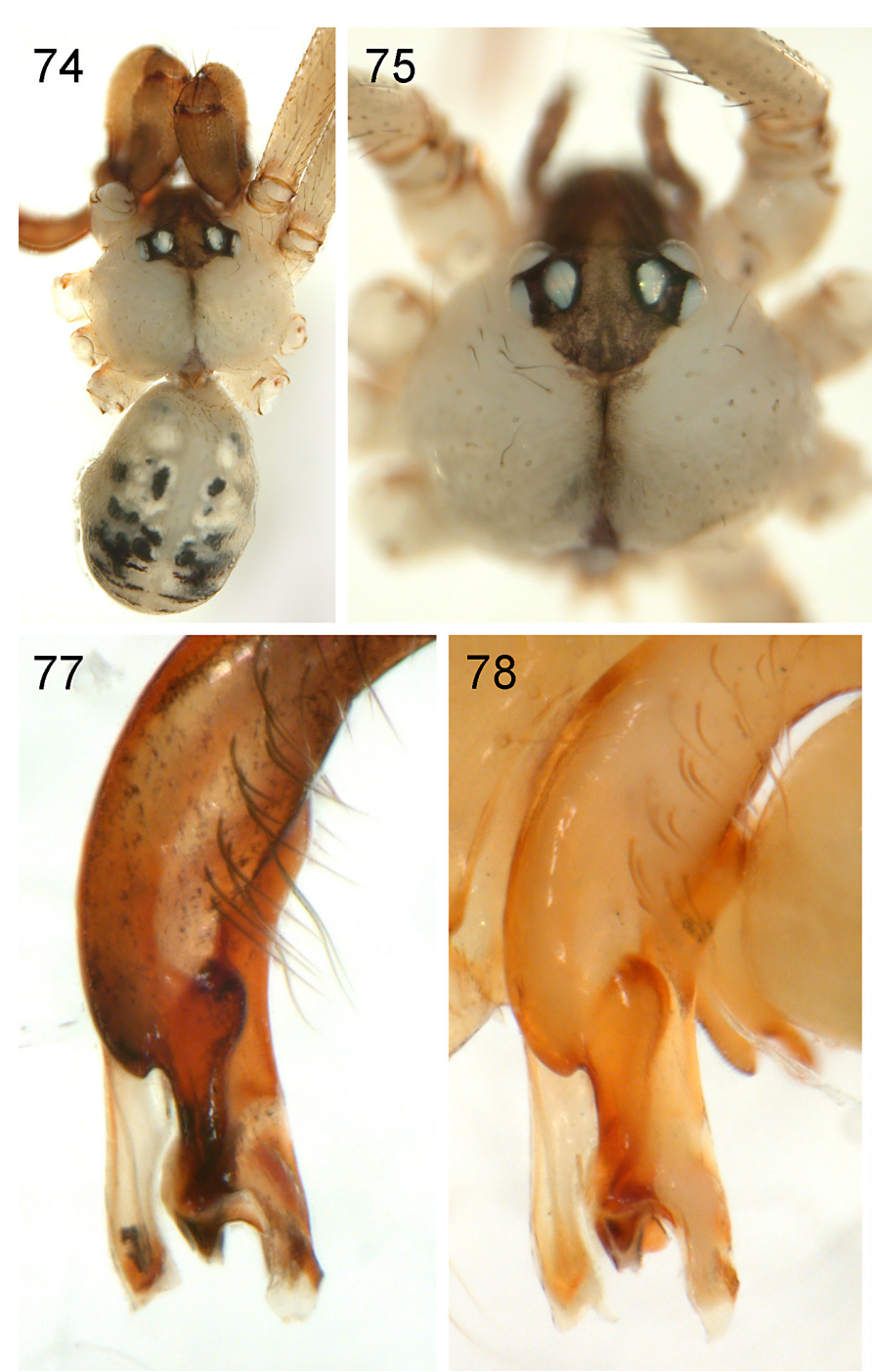
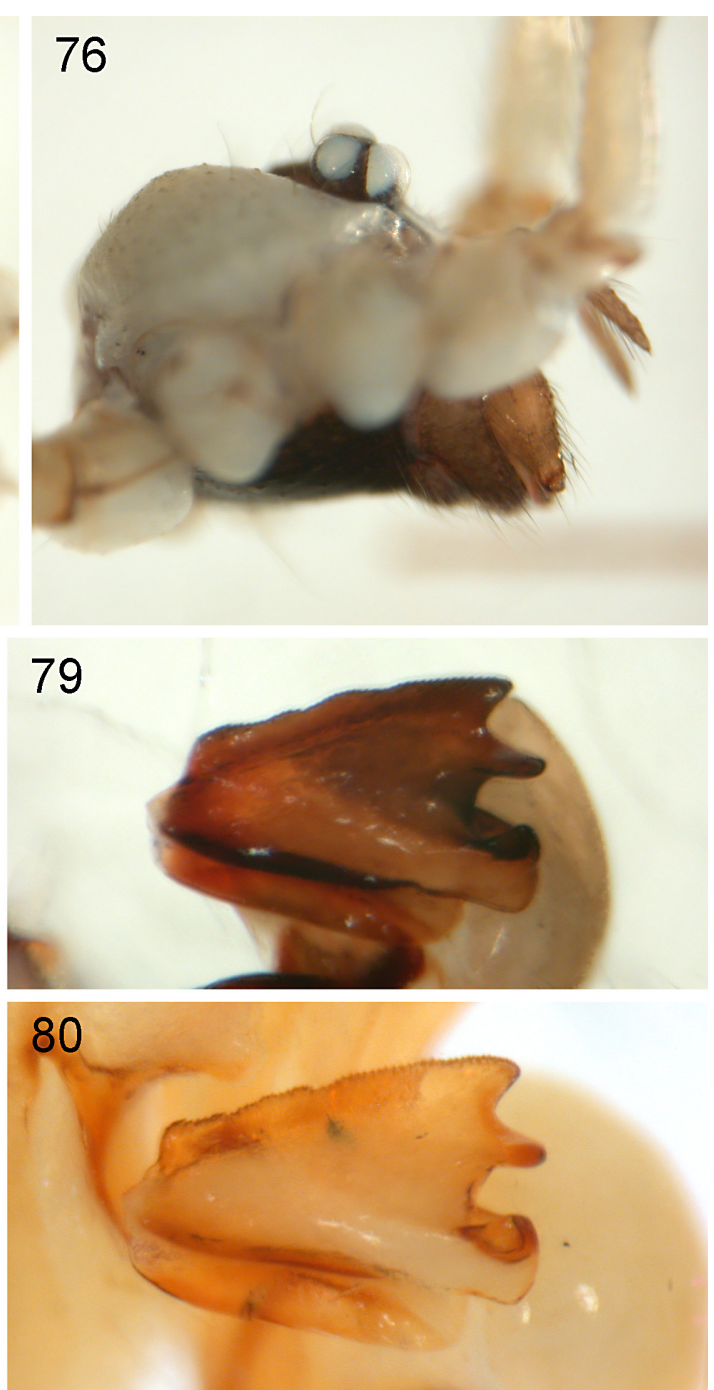

Figs 74-80. Savarna miser (Bristowe, 1952). 74. ^ from Batu Caves, dorsal view. 75-76. $ᄋ$ from Batu Caves, prosoma in dorsal and lateral views. 77-78. Right procursi, retrolateral views, $\widehat{\partial} \partial$ from Batu Caves (77) and from cave near Baso (holotype of Spermophora baso Roewer, 1963; 78). 79-80. Right bulbal processes, $\widehat{\partial} \widehat{\jmath}$ from Batu Caves (79) and from cave near Baso (holotype of Spermophora baso Roewer, 1963; 80). At varying scales. 


\section{Female}

In general similar to male; eye triads closer together (PME-PME distance: $150 \mu \mathrm{m}$ ); clypeus unmodified; leg tibiae with usual low density of vertical hairs. Tibia 1: 5.4 (missing or detached in other specimens). Epigynum slightly protruding (Fig. 35), with wide transversal sclerotized plate with pair of semicircular

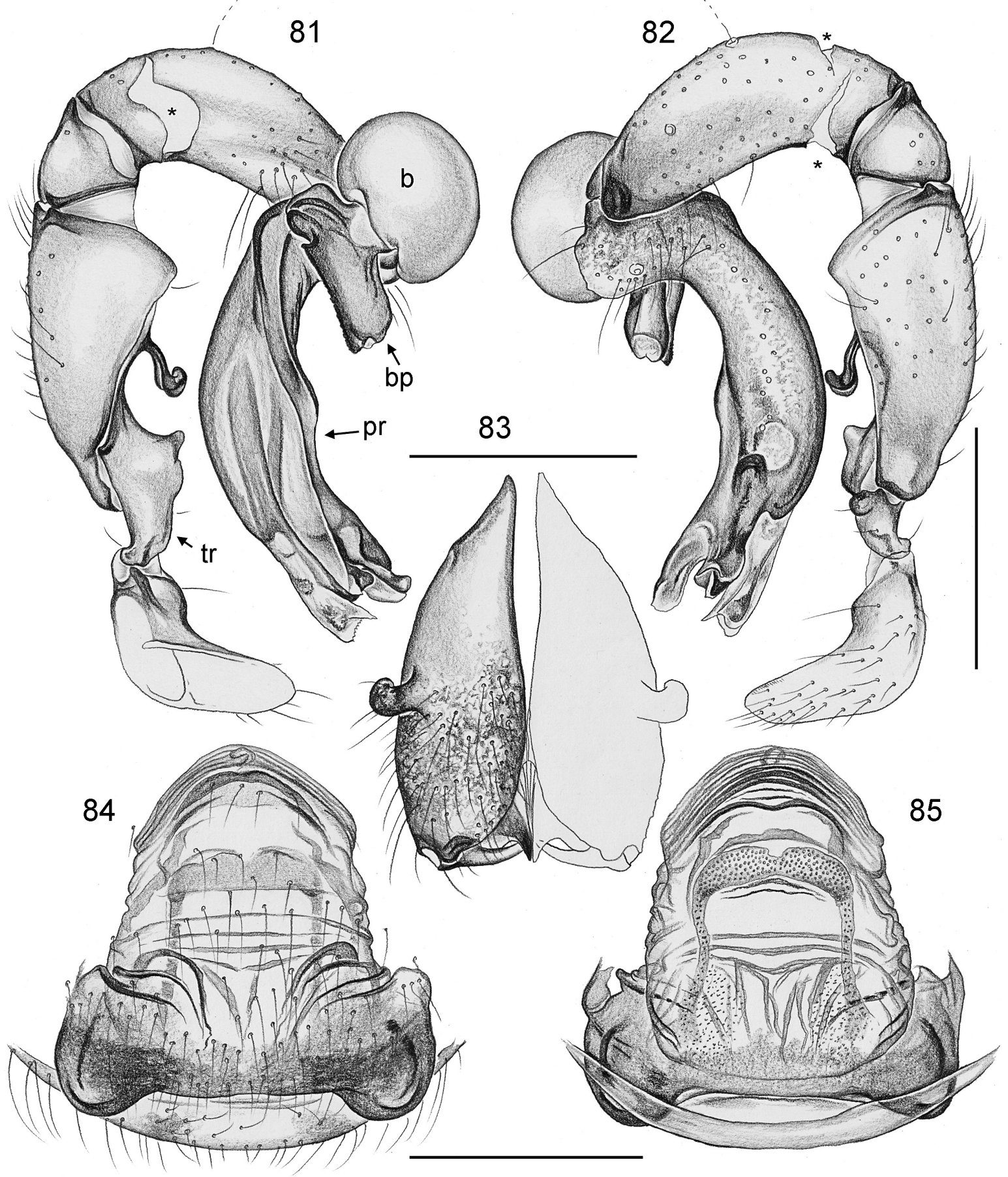

Figs 81-85. Savarna miser (Bristowe, 1952). 81-82. Left male palp, prolateral and retrolateral views $(b=$ genital bulb; $b p=$ bulbal process; $p r=$ procursus; $\operatorname{tr}=$ trochanter; asterisks $=$ broken tibia $) .83$. Male chelicerae, frontal view. 84-85. Cleared female genitalia, ventral and dorsal views. Scale bars: $83=0.3 \mathrm{~mm} ; 81-82,84-85=0.5 \mathrm{~mm}$. 
posterior extensions (Figs 34, 38, 84); internal genitalia as in Figs 39 and 85, pore plates contiguous (whether the sclerotized bars extending toward posterior are also provided with pores is not clear).

\section{Distribution}

Known from two localities in mainland Malaysia and Sumatra (Fig. 1); but see Addendum.

\section{Acknowledgements}

We thank Julia Altmann for sending the holotype of Spermophora baso on loan; Peter Jäger for the loan of newly collected S. miser specimens; Venus Saksongmuang for accompanying us in the field; our drivers Usman Hayee-Aarwae, Jeerabute Suwannatut and Preesha Petsout for bringing us safely to all requested places; the National Research Council of Thailand (NRCT) for issuing the relevant permits; two anonymous reviewers for their comments, which helped improve the manuscript; and the German Research Foundation for financial support (DFG Project HU 980/11-1).

\section{References}

Bristowe W.S. 1952. The arachnid fauna of the Batu Caves in Malaya. Annals and Magazine of Natural History 12 (5): 697-707. http://dx.doi.org/10.1080/00222935208654340

Brown B.V. 1993. A further chemical alternative to critical-point-drying for preparing small (or large) flies. Fly Times 11: 10.

Huber B.A. 2005. Revision of the genus Spermophora Hentz in Southeast Asia and on the Pacific Islands, with descriptions of three new genera (Araneae: Pholcidae). Zoologische Mededelingen 79-2 (4): 61-114.

Huber B.A. 2011. Revision and cladistic analysis of Pholcus and closely related taxa (Araneae, Pholcidae). Bonner zoologische Monographien 58: 1-509. Available from http://biodiversitylibrary.org/ page/44833941 [accessed 20 Oct. 2015]

Huber B.A. 2013. Revision and cladistic analysis of the Guineo-Congolian spider genus Smeringopina Kraus (Araneae, Pholcidae). Zootaxa 3713: 1-160. http://dx.doi.org/10.11646/zootaxa.3713.1.1

Huber B.A. \& Fleckenstein N. 2008. Comb-hairs on the fourth tarsi in pholcid spiders (Araneae, Pholcidae). Journal of Arachnology 36: 232-240. http://dx.doi.org/10.1636/CSh07-71.1

Laidlaw F.F. 1900. On the frogs collected during the "Skeat Expedition" to the Malay Peninsula, 1899-1900. Proceedings of the Zoological Society of London 1900: 883-890. Available from http:// biodiversitylibrary.org/page/31098668 [accessed 20 Oct. 2015]

Roewer C.F. 1963. Über einige neue Arachniden (Opiliones und Araneae) der orientalischen und australischen Region. Senckenbergiana Biologica 44 (3): 223-230.

Simon E. 1901. On the Arachnida collected during the "Skeat Expedition" to the Malay Peninsula, 1899-1900. Proceedings of the Zoological Society of London 1901 (2): 45-84. Available from http:// biodiversitylibrary.org/page/35988105 [accessed 20 Oct. 2015]

Wongprom P. \& Wiwatwitaya D. 2015. One new species of the genus Savarna Huber, 2005 (Araneae, Pholcidae) from southern Thailand. ZooKeys 498: 1-5. http://dx.doi.org/10.3897/zookeys.498.9269

\section{Addendum}

On the type locality of Spermophora baso Roewer, 1963:

During the proofing stage of the present paper (in October 2015), the first author visited Baso Cave in Central Sumatra, the supposed type locality of Spermophora baso Roewer, 1963 [= Savarna miser 
(Bristowe, 1952)]. The result of this visit, together with other circumstantial evidence, suggests that Roewer's locality information is wrong:

1. Despite intensive search, no Savarna was found in or at Baso Cave. The cave (entrance at $0.2478^{\circ}$ $\mathrm{S}, 100.4830^{\circ} \mathrm{E}, \sim 760 \mathrm{~m}$ a.s.l.) is used for extracting sand by boat and manual work but appears to be in good condition. Large numbers of bats, swifts, crickets, millipedes, and several families of spiders were observed in the cave. It seems unlikely that Savarna miser has disappeared due to environmental degradation.

2. Savarna has not been found at any other locality in Sumatra, including another cave $13 \mathrm{~km} \mathrm{E}$ of Baso Cave (Ngalau Indah Cave, entrance at $0.2549^{\circ} \mathrm{S}, 100.6036^{\circ} \mathrm{E}, \sim 630 \mathrm{~m}$ a.s.l., visited by the first author in Oct. 2015) and numerous other localities visited by several collectors in North, Central, and South Sumatra. This makes the male holotype of Spermophora baso the only specimen of Savarna supposedly originating from outside the Malay Peninsula.

3. It has been noted before (Herversen \& Martens 1972) that in Roewer's arachnid collection wrong localities are given for numerous type specimens. The authors remain silent about possible origins of these errors but they strongly suggest that all of Roewer's locality data need to be reevaluated with particular skepticism (“...grundsätzlich besonders kritisch zu beurteilen”).

4. It is remarkable that the type localities of Savarna miser (Bristowe, 1952) and of its junior synonym Savarna baso (Roewer, 1963) have fairly similar names: Batu Cave and Baso Cave. Whether this similarity has anything to do with the origin of the labeling error is unknown, but it seems much more likely that the actual type locality of Savarna baso is indeed Batu Cave in Kuala Lumpur rather than Baso Cave in Sumatra.

\section{Reference}

Herversen O. \& Martens J. 1972. Unrichtige Fundort-Angaben in der Arachniden-Sammlung Roewer. Senckenbergiana biologica 53 (1/2): 109-123.

Manuscript received: 21 August 2015

Manuscript accepted: 8 October 2015

Published on: 10 December 2015

Topic editor: Rudy Jocqué

Desk editor: Danny Eibye-Jacobsen

Printed versions of all papers are also deposited in the libraries of the institutes that are members of the EJT consortium: Muséum National d'Histoire Naturelle, Paris, France; Botanic Garden Meise, Belgium; Royal Museum for Central Africa, Tervuren, Belgium; Natural History Museum, London, United Kingdom; Royal Belgian Institute of Natural Sciences, Brussels, Belgium; Natural History Museum of Denmark, Copenhagen, Denmark. 